\title{
HUBUNGAN ANTARA UMUR, TINGKAT PENDIDIKAN DAN PERILAKU PETANI DALAM PENGGUNAAN PESTISIDA \\ (Studi Kasus Di Kelurahan Jogomerto Kecamatan Tanjunganom Kabupaten Nganjuk Tahun 2017) \\ Miftachul Jannah, Koerniasari, Bambang Sunarko
}

\begin{abstract}
ABSTRAK
Farmer's behavior, level of education, and ages which are low is the factor that causes the usage of pesticide is out of the guidelines by the farmers nowadays. Using pesticide without following the guidelines will cause negative impact for the farmers their selves especially in health aspect. The research was purposed to find out the relationship between ages, level of education, and farmer's behavior in using pesticide by interviewing and observing the farmers while working and using the pesticide.

Based on the characteristic, this is an observational research with cross sectional approaching. Interviews and observation are the method that is used to collect the data. 86 populations of farmers and 71 sampling are selected to participate in the research. Then the data will be analyzed by trial chi-square technique in a computer.

The result showed $46.5 \%$ productive farmers is about 16 to 64 years-old and $32.5 \%$ farmers have good enough behavior that used pesticide out of the guidelines, significantly affects $(p<0.05)$, and does not affect $(p>0.05)$ that is the level of education.

That is why the writer recommends next movement in order to follow the guidelines of using pesticide by giving socialization to the farmers and adding their education of how to use pesticide properly. The governments need to give counseling and socialization routinely for the farmers in order to avoid the danger of pesticide just like poisoning.

Reading List : 22 pieces (1990-2016)

Classification :-

Keywords : farmers' individual factor, pesticide usage
\end{abstract}

\section{PENDAHULUAN}

Pestisida untuk saat sekarang ini bukanlah barang aneh bagi petani, sekalipun petani tersebut tinggal di desa yang terpencil. Pengendalian hama, penyakit dan gulma dengan pestisida telah lama dilakukan oleh petani di Indonesia, yaitu sejak pengendalian hama, penyakit dan gulma dimasukkan ke dalam program BIMAS dan INMAS, untuk meningkatkan produksi padi sekitar tahun 1970-an. (Rini wudianto, 1990 : 3)

\begin{abstract}
Pestisida merupakan pilihan utama bagi para petani untuk mengendalikan hama, penyakit dan gulma karena dapat membunuh langsung jasad pengganggu. Para petani berfikiran bahwa pemakaian pestisida dengan menggunakan dosis yang lebih dari yang dianjurkan dapat memperoleh hasil yang lebih baik pada tanamannya, namun petani tidak tahu akan bahaya terhadap hasil panennya maupun terhadap kesehatan. Jika penggunaan pestisida berlebih maka akan menimbulkan
\end{abstract}


residu pestisida penempel pada tanaman.

Penggunaan dosis pestisida yang berlebih dapat membahayakan kesehatan petani dan konsumen, mikroorganisme non target serta berdampak pada pencemaran lingkungan baik itu tanah dan air.

Bahaya yang dapat ditimbulkan oleh pestisida diantaranya pestisida meracuni manusia tidak hanya saat pestisida itu digunakan, tapi bisa juga saat dipersiapkan untuk penyemprotan, atau sesudah melakukan penyemprotan. Keracunan bisa melalui kulit mata dan mulut serta pernafasan. Demi keselamatan manusia dan lingkungan sekitarnya, pemerintah juga telah mengeluarkan peraturan No. 107 Tahun 2014 yang berisi tentang pengawasan pestisida.

Pengawasan pestisida sangatlah penting karena para petani atau pekerja-pekerja pertanian kurang menyadari daya racun pestisida, sehingga dalam melakukan penyimpanan dan penggunaannya tidak memperhatikan segi-segi keselamatan. Pestisida sering kali mereka tempatkan di dapur, dan saat menyemprot tidak menggunakan pelindung diri, misalnya sarung tangan, baju lengan panjang dan masker. Semua tindakan seperti itu tentunya kurang tepat. Penyimpanan yang kurang baik akan mudah di jangkau oleh anak-anak atau orangorang yang tidak mengetahui bahwa itu merupakan pestisida. (Rini Wudianto, $1990: 2$ )

Perilaku penggunaan pestisida yang tidak sesuai pedoman dimungkinkan oleh faktor yang ada dalam diri petani, yaitu pendidikan dan pengetahuan petani tentang penggunaan pestisida yang masih kurang tepat. Pendidikan dan pengetahuan yang cukup akan memberikan apresiasi dan pertimbangan yang mengarah pula pada peilaku yang baik dalam penggunaan pestisida dan penanganan kemasannya oleh petani.

Desa Jogomerto merupakan salah satu desa dengan wilayah pertanian yang cukup luas di Kabupaten Nganjuk Jawa Timur. Luas tanah di daerah tersebut sebesar $283,880 \mathrm{Ha}$, dan lahan pertanian sebesar 132,820 Ha. Hal tersebut berarti sekitar $47 \%$ luas tanah di Desa Jogomerto masih menjadi lahan pertanian dan belum ada pembangunan. Sehingga mata pencarian utama penduduk di daerah tersebut adalah sebagai petani. Petani di desa tersebut kebanyakan menggunakan insektisida sebagai pembasmi hama dan herbisida sebagai pembasmi gulma. Insektisida yang biasa digunakan adalah insektisida golongan karbamat untuk membasmi wereng dan insektisida berbahan aktif karbofuran yang memiliki nama dagang Furadan $3 G$, Curater 3G, Dharmafur 3G dan Petrofur $3 G$ digunakan untuk mengendalikan hewan penggerek padi. Namun di daerah tersebut petani masih belum menyadari tingkat bahaya pestisida terhadap kesehatan manusia dan lingkungan, sehingga dalam penggunan pestisida di lingkungan masih kurang tepat dan tidak sesuai pedoman.

Dari hasil survei pendahuluan yang dilakukan terhadap 15 orang dari total populasi sebanyak 86 petani, 12 orang masih menggunakan pestisida dengan kurang tepat diantaranya menyimpan dan meletakkan pestisida di dapur, mengaduk atau mencampur pestisida dengan tangan dan menggunakan pestisida tidak sesuai dosis dan takaran. Sedangkan 3 orang sudah menggunakan pestisida secara tepat diantaranya sudah memiliki gudang sendiri untuk menyimpan pestisida. Selain itu, petani juga melakukan penyemprotan pestisida 
pada tanaman tanpa menggunakan pengaman yang lengkap.

Para petani beranggapan bahwa hal tersebut tidak menjadi masalah, asalkan produksi pertanian mereka terjaga dari hama, penyakit dan gulma. Sedangkan dari hasil wawancara yang dilakukan, keluhan petani seperti pusing, mual-mual dan sering linu-linu bahkan kaku di beberapa bagian tubuh sering terjadi. Namun mereka menganggap hal tersebut biasa terjadi dan akan hilang dengan sendirinya.

\section{METODE PENELITIAN}

Penelitian ini merupakan penelitian analitik, karena penelitian ini diarahkan untuk menjelaskan suatu keadaan atau situasi. Penelitian ini menggunakan studi Cross Sectional karena variabel sebab atau resiko dan akibat atau kasus yang terjadi pada objek penelitian diukur atau

\section{HASIL DAN PEMBAHASAN}

\section{A.Karakteristik}

\section{Berdasarkan Umur}

Dari hasil penilaian 71Petani di Kelurahan Jogomerto, Kecamatan
Hal tersebut dikarenakan tingkat pendidikan dan perilaku petani terhadap pestisida didaerah tersebut masih sangat rendah. Bertitik tolak dari kegiatan tersebut di atas, maka perlu dilakukan penelitian tentang "HUBUNGAN ANTARA UMUR, TINGKAT PENDIDIKAN, DAN PERILAKU PETANI DALAM PENGGUNAAN PESTISIDA (Studi Kasus Di Kelurahan Jogomerto Kecamatan Tanjunganom Kabupaten Nganjuk Tahun 2017)"'

dikumpulkan dalam waktu yang bersamaan. Populasi pada penelitian ini sebanyak 86 petani dan secara random sampling di dapat sebanyak 71 petani. Metode yang digunakan dalam penelitian ini yaitu menggunakan metode wawancara, observasi dan kuesioner.

Tanjunganom, Kabupaten Nganjuk Tahun 2017, didapatkan hasil karakteristik responden berdasarkan umur adalah sebagai berikut :

Tabel IV.1

HASIL REKAPITULASI KARAKTERISTIK

RESPONDENBERDASARKAN UMUR DIKELURAHAN JOGOMERTO KECAMATAN TANJUNGANOM KABUPATEN NGANJUK TAHUN 2017

\begin{tabular}{|c|c|c|}
\hline UMUR & $\begin{array}{c}\text { JUMLAH } \\
\text { RESPONDEN }\end{array}$ & PERSEN \\
\hline$\leq 15$ & 0 & $0,0 \%$ \\
\hline 16sampai 64 & 60 & $84,5 \%$ \\
\hline$\geq 65$ & 11 & $15,5 \%$ \\
\hline Total & 71 & $100,0 \%$ \\
\hline
\end{tabular}

Hasil penelitian tentang karakteristik responden menurut umur paling tinggi terdapat pada kelompok umur antara 16 sampai 64 tahun yaitu sebanyak 84,5\%.Menurut UndangUndang Tenaga Kerja No. 13 Tahun 
2003 kelompok umur tersebut merupakan kelompok umur produktif dalam bekerja. Kelompok umur produktif lebih giat dan lebih cepat dalam bekerja, hal tersebut di karenakan kekuatan tubuh yang masih belum melemah.

\section{B. Karakteristik Responden Berdasarkan Tingkat Pendidikan}

Dari hasil penilaian 71petani di KelurahanJogomerto, Kecamatan Tanjunganom,Kabupaten Nganjuk Tahun 2017, didapatkan hasil karakteristik responden berdasarkan tingkat pendidikan adalah sebagai berikut :

Tabel IV.2

HASIL REKAPITULASI KARAKTERISTIK RESPONDEN BERDASARKAN TINGKAT PENDIDIKAN

DIKELURAHANJOGOMERTO KECAMATAN TANJUNGANOM KABUPATEN NGANJUK TAHUN 2017

\begin{tabular}{|l|c|c|}
\hline \multicolumn{1}{|c|}{ TINGKAT PENDIDIKAN } & JUMLAH PETANI & PERSEN \\
\hline Tamat SD sederajat & 28 & $39,4 \%$ \\
\hline Tamat SMP sederajat & 30 & $42,3 \%$ \\
\hline Tamat SMA sederajat & 12 & $16,9 \%$ \\
\hline Tamat Perguruan Tinggi & 1 & $1,4 \%$ \\
\hline \multicolumn{1}{|c|}{ Total } & 71 & $100,0 \%$ \\
\hline \hline
\end{tabular}

Hasil penelitian tentang tingkat pendidikan responden, paling tinggiterdapat pada tingkat pendidikan tamat SMP sederajat sebesar $42,3 \%$. Dari data tersebut yang memiliki persentase tinggi yaitu jenjang pendidikan formal berupa pendidikan menengah. Hal ini disebabkan oleh letak geografis kelurahan yang letaknya cukup jauh dari kotabesar. Hal ini sesuai dengan pendapat dari Hasbullah (2005), bahwa faktor-faktor yang mempengaruhi tingkat pendidikan antara lain ideologi, sosialekonomi, sosial budaya, perkembangan ilmu pengetahuan dan teknologidan teknologi, dan psikologi.

\section{Perilaku Petani}

Dari hasil penilaian 71 petani di KelurahanJogomerto, Kecamatan Tanjunganom,Kabupaten Nganjuk Tahun 2017, didapatkan hasil perilaku petani adalah sebagai berikut :

Tabel IV.3

HASIL REKAPITULASI KARAKTERISTIK RESPONDEN BERDASARKAN PERILAKU DIKELURAHANJOGOMERTO KECAMATAN TANJUNGANOM KABUPATEN NGANJUK TAHUN 2017

\begin{tabular}{|c|l|c|c|}
\hline NO. & \multicolumn{1}{|c|}{ PERILAKU PETANI } & $\begin{array}{c}\text { JUMLAH } \\
\text { ORANG }\end{array}$ & $\begin{array}{c}\text { PERSENTAE } \\
(\%)\end{array}$ \\
\hline 1. & Baik & 0 & 0,0 \\
\hline 2. & Cukup Baik & 68 & 95,8 \\
\hline 3. & Kurang Baik & 3 & 4,2 \\
\hline \multicolumn{2}{|c|}{ Jumlah } & 71 & 100,0 \\
\hline
\end{tabular}


Hasil penelitian perilaku petani terhadap penggunaan pestisida di Kelurahan Jogomerto Kecamatan Tanjunganom Kabupaten Nganjuk menunjukkan tidak ada petani yang memiliki perilaku baik. Namun banyak petani yang memiliki perilaku cukup baik yaitu sebanyak 68 orang $(95,8 \%)$ dan yang memiliki perilaku kurang baik sebanyak 3 orang $(4,2 \%)$.

Berdasarkan hasil penelitian tersebut, orang yang memiliki perilaku baik memiliki presentase paling rendah. Faktor-faktor yang mempengaruhi perilaku petani salah satunya adalah kurang mengertinya pengetahuan masyarakat tentang dampak yang diakibatkan dari penggunaan pestisida.Pengetahuan merupakan hasil dari tahu, dan ini terjadi setelah orang melakukan pengindraan terhadap suatu objek tertentu. Pengetahuan dapat diperoleh dari pengalaman diri sendiri pengalaman orang lain maupun lingkungan. Perilaku seseorang akan lebih langgeng apabila didasari oleh pengetahuan. Pengetahuan diperlukan sebagai dorongan dalam menimbulkan sikap dan perilaku (Notoatmodjo, 2007).

\section{Penggunaan Pestisida Oleh Petani}

Dari hasil pengamatan 71 petani di KelurahanJogomerto, Kecamatan Tanjunganom,Kabupaten Nganjuk Tahun 2017, didapatkan hasil observasi penggunaan pestisida oleh petani adalah sebagai berikut :

Tabel IV.5

HASIL REKAPITULASI RESPONDEN BERDASARKAN

PENGGUNAAN PESTISIDA DIKELURAHANJOGOMERTO

KECAMATAN TANJUNGANOM KABUPATEN NGANJUK

TAHUN 2017

\begin{tabular}{|c|c|c|c|}
\hline NO. & $\begin{array}{c}\text { PENGGUNAAN } \\
\text { PESTISIDA }\end{array}$ & $\begin{array}{c}\text { JUMLAH } \\
\text { ORANG }\end{array}$ & $\begin{array}{c}\text { PERSENTAE } \\
(\%)\end{array}$ \\
\hline 1. & Sesuai Pedoman & 43 & 60,6 \\
\hline 2. & Tidak Sesuai Pedoman & 29 & 39,4 \\
\hline \multicolumn{2}{|c|}{ Jumlah } & 71 & 100,0 \\
\hline
\end{tabular}

Hasil penelitian penggunaan pestisida oleh petani yang dilakukan dengan caraobservasi menggunakan lembar observasi menunjukkan bahwa penggunaan pestisida yang sesuai pedoman memiliki persentase tertinggi sebesar $60,6 \%$. Pestisida yang anyak digunakan oleh petani adalah pestisida jenis insektisida, herbisida dan fungisida untuk mengendalikan hama dan binatang penganggu yang dapat merusak tanaman padi petani.

Berdasarkan hasil penelitian tersebut penggunaan pestisida yang tidak sesuai pedoman dikarenakan sikap petani yang belum tentu sesuai dengan tindakan petani. Petani tidak mematuhi syarat-syarat keselamatan dalam menggunakan pestisida dan merasa tidak terganggu meskipun telah menggunakan pestisida selama bertahun-tahun (Djojosumarto, 2008).

\section{E. Hubungan Umur dengan Penggunaan Pestisida}

Dari hasil penilaian 71 petani di Kelurahan Jogomerto, Kecamatan Tulungagung, Kabupaten Nganjuk Tahun 2017,dapat diketahui hubungan umur dengan penggunaan pestisida sebagai berikut : 
Tabel IV.6

HUBUNGAN UMURRESPONDEN DENGAN PENGGUNAAN

PESTISIDA DIKELURAHAN JOGOMERTO KECAMATAN

TANJUNGANOM KABUPATEN NGANJUK TAHUN 2017

\begin{tabular}{|c|c|c|c|c|c|}
\hline \multirow[t]{2}{*}{ NO. } & \multirow[t]{2}{*}{$\begin{array}{c}\text { UMUR } \\
\text { RESPONDEN }\end{array}$} & \multicolumn{2}{|c|}{$\begin{array}{l}\text { PENGGUNAAN } \\
\text { PESTISIDA }\end{array}$} & \multirow[b]{2}{*}{ TOTAL } & \multirow[b]{2}{*}{$\mathrm{P}$} \\
\hline & & $\begin{array}{c}\text { SESUAI } \\
\text { PEDOMAN }\end{array}$ & $\begin{array}{c}\text { TIDAK } \\
\text { SESUAI } \\
\text { PEDOMAN }\end{array}$ & & \\
\hline 1. & $\begin{array}{l}\text { Umur } \\
\text { Produktif } \\
\text { (16-64 Tahun) }\end{array}$ & $\begin{array}{c}33 \\
(46,5 \%)\end{array}$ & $\begin{array}{c}27 \\
(38,0 \%)\end{array}$ & $\begin{array}{c}60 \\
(84,5 \%)\end{array}$ & \multirow[t]{3}{*}{0,025} \\
\hline 2. & $\begin{array}{l}\text { Umur Tua } \\
\text { ( } \geq 65 \text { Tahun) }\end{array}$ & $\begin{array}{c}10 \\
(14,1 \%)\end{array}$ & $\begin{array}{c}1 \\
(1,4 \%)\end{array}$ & $\begin{array}{c}11 \\
(15,5 \%)\end{array}$ & \\
\hline & Total & $\begin{array}{c}43 \\
(60,6 \%) \\
\end{array}$ & $\begin{array}{c}28 \\
(39,4 \%) \\
\end{array}$ & $\begin{array}{c}71 \\
(100,0 \%)\end{array}$ & \\
\hline
\end{tabular}

Dengan mengetahui umur responden denganpenggunaan pestisida maka dapat diketahui mayoritas penggunaan pestisida sesuai pedoman pada umur produktif yaitu sebesar $46,5 \%$.

Hasil Chi Square yang dilakukan menunjukkan signifikan 0,025 yang berarti $\mathrm{HO}$ ditolak sehingga ada hubungan antara umur dengan penggunaan pestisida di KelurahanJogomerto Kecamatan Tanjunganom Kabupaten Nganjuk. Hal ini dapat terjadi karena umur yang produktif juga mempengaruhi kerja petani dalam menggunakan pestisida.

Tabel IV.7

HUBUNGAN TINGKAT PENDIDIKANRESPONDENDENGAN

PENGGUNAAN PESTISIDA DIKELURAHAN JOGOMERTO

KECAMATAN TANJUNGANOM KABUPATEN NGANJUK TAHUN 2017

\begin{tabular}{|c|c|c|c|c|c|}
\hline & & \multicolumn{2}{|c|}{$\begin{array}{r}\text { PENGGUNAAN } \\
\text { PESTISIDA }\end{array}$} & \\
\cline { 3 - 4 } NO. & TINGKAT & \multicolumn{2}{|c|}{ TOTAL } & P \\
\cline { 3 - 4 } & PENDIDIKAN & $\begin{array}{c}\text { SESUAI } \\
\text { PEDOMAN }\end{array}$ & $\begin{array}{c}\text { TIDAK } \\
\text { SESUAI } \\
\text { PEDOMAN }\end{array}$ & & \\
\hline 1. & SD Sederajat & $\begin{array}{c}19 \\
(26,8 \%)\end{array}$ & 9 & & \\
\hline
\end{tabular}




\begin{tabular}{|c|c|c|c|c|c|}
\hline & & & $(12,7 \%)$ & $\begin{array}{c}28 \\
(39,9 \%)\end{array}$ & 0,567 \\
\hline 2. & $\begin{array}{l}\text { SMP } \\
\text { Sederajat }\end{array}$ & $\begin{array}{c}17 \\
(23,9 \%)\end{array}$ & $\begin{array}{c}13 \\
(18,3 \%)\end{array}$ & $\begin{array}{c}30 \\
(42,3 \%)\end{array}$ & \\
\hline 3. & $\begin{array}{l}\text { SMA } \\
\text { Sederajat }\end{array}$ & $\begin{array}{c}6 \\
(8,5 \%)\end{array}$ & $\begin{array}{c}6 \\
(8,5 \%)\end{array}$ & $\begin{array}{c}12 \\
(16,9 \%)\end{array}$ & \\
\hline 4. & $\begin{array}{l}\text { Perguruan } \\
\text { Tinggi }\end{array}$ & $\begin{array}{c}1 \\
(1,4 \%)\end{array}$ & $\begin{array}{c}0 \\
(0,0 \%)\end{array}$ & $\begin{array}{c}1 \\
(1,4 \%)\end{array}$ & \\
\hline & Total & $\begin{array}{c}43 \\
(60,6 \%)\end{array}$ & $\begin{array}{c}28 \\
(39,4 \%)\end{array}$ & $\begin{array}{c}71 \\
(100 \%)\end{array}$ & \\
\hline
\end{tabular}

\begin{abstract}
Dengan mengetahui tingkat pendidikan responden dengan penggunaan pestisida maka dapat diketahui mayoritas pendidikan responden lulus SMP sederajat yaitu sebesar 42,3\%. Bila hal ini dikaitkan dengan penggunaan pestisida akan diperoleh hasil yang bervariasi, dimana tingkat pendidikan yang tinggi maupun rendah tidak diikuti oleh penggunaan pestisida yang sesuai pedoman. Hal ini disebabkan karena pengetahuan responden dalam penggunaan pestisida. Semakin tinggitingkat pendidikan responden semakin baik juga pengetahuan responden dala penggunaan pestisida.Hal ini sesuai dengan yang diungkapkan (Gumiarti, 2002) dimana tingkat pendidikan seseorang akan mempengaruhi tingkat penerimaan dan pemahaman terhadap suatu objek atau materi yang di manifestasikan dalam bentuk pengetahuan. Semakin tinggi jenjang pendidikan seseorang akan mempengaruhi tingkat

Tanjunganom Kabupaten Nganjuk. Dari data yang diperoleh, tidak hanya responden berpendidikan tinggi yang menggunakan pestisida sesuai pedoman, responden dengan pendidikan menengah pun juga ada yang menggunakan pestisida sesuai pedoman. Hal ini dapat di sebabkan karena adanya faktor-faktor selain pendidikan yang mempengaruhi seberapa besar informasi yang mempengaruhi penggunaan pestisida seperti : pekerjaan, umur, media cetak, media informasi dan media sosial lainnya (Wawan, 2010). Namun ketika seseorang dengan pendidikan rendah mau dan mampu untuk menggali potensi yang dimilikinya dengan cara membaca, mendengarkan berita,tidak harus sekolah, maka disini pengetahuan baik belum tentu pendidikannya tinggi. Karena orang yang berpendidikan rendah bisa mencari informasi dengan membaca, mendengarkan untuk mendapatkan pengetahuan yang baik.
\end{abstract} penguasaan terhadap materi yang harus dikuasai sesuai dengan tujuan dan sasaran.

Hasil Chi Square yang dilakukan menunjukkan signifikan 0,567 yang berarti $\mathrm{HO}$ diterima sehingga tidak ada hubungan antara tingkat pendidikan dengan penggunaan pestisida di KelurahanJogomerto Kecamatan

\section{G. Hubungan Perilaku dengan Penggunaan Pestisida}

Dari hasil penilaian 71 petani di Kelurahan Jogomerto, Kecamatan Tulungagung, Kabupaten Nganjuk Tahun 2017,dapat diketahui hubungan perilaku dengan penggunaan pestisida sebagai berikut 
Tabel IV.8

HUBUNGAN PERILAKU RESPONDEN DENGAN PENGGUNAAN

PESTISIDA DI KELURAHAN JOGOMERTO KECAMATAN

TANJUNGANOM KABUPATEN NGANJUK TAHUN 2017

\begin{tabular}{|c|c|c|c|c|c|}
\hline \multirow[t]{2}{*}{ NO. } & \multirow[t]{2}{*}{ PERILAKU } & \multicolumn{2}{|c|}{$\begin{array}{l}\text { PENGGUNAAN } \\
\text { PESTISIDA }\end{array}$} & \multirow[b]{2}{*}{ TOTAL } & \multirow[b]{2}{*}{$P$} \\
\hline & & $\begin{array}{c}\text { SESUAI } \\
\text { PEDOMAN }\end{array}$ & $\begin{array}{c}\text { TIDAK } \\
\text { SESUAI } \\
\text { PEDOMAN }\end{array}$ & & \\
\hline 1. & Baik & $\begin{array}{c}0 \\
(0,0 \%)\end{array}$ & $\begin{array}{c}0 \\
(0,0 \%)\end{array}$ & $\begin{array}{c}0 \\
(0,0 \%)\end{array}$ & \multirow{4}{*}{0,028} \\
\hline 2. & Cukup Baik & $\begin{array}{c}43 \\
(60,6 \%)\end{array}$ & $\begin{array}{c}25 \\
(35,2 \%)\end{array}$ & $\begin{array}{c}68 \\
(95,8 \%)\end{array}$ & \\
\hline 3. & Kurang Baik & $\begin{array}{c}0 \\
(0,0 \%)\end{array}$ & $\begin{array}{c}3 \\
(4,2 \%)\end{array}$ & $\begin{array}{c}3 \\
(4,2 \%)\end{array}$ & \\
\hline & Total & $\begin{array}{c}43 \\
(60,6 \%)\end{array}$ & $\begin{array}{c}28 \\
(39,4 \%)\end{array}$ & $\begin{array}{c}71 \\
(100 \%)\end{array}$ & \\
\hline
\end{tabular}

Dari hasil wawancara dengan lembar kuisioner menunjukkan bahwa responden yang memiliki perilaku baik dan menggunakan pestisida sesuai pedoman dan tidak sesuai pedoman. Responden yang memiliki perilaku cukup baik dan menggunakan pestisida sesuai pedoman sebesar 43 orang $(60,6 \%)$ sedangkan yang menggunakan pestsida tidak sesuai pedoman sebesar 25 orang (35,2\%). Dan tidak ada responden yang memiliki perilaku kurang baik dan menggunakan pestisida sesuai pedoman, sedangkan yang menggunakan pestisida tidak sesuai pedoman sebesar 3 orang $(4,2 \%)$.

Berdasarkan hasil tersebut, perilaku responden cukup baik, hal ini karena responden ada yang sudah menggunakan pestisida sesuai dengan pedoman. Hasil Chi Square yang dilakukan menunjukkan signifikan 0,028 yang berarti $\mathrm{HO}$ ditolak sehingga ada hubungan antara perilaku dengan penggunaan pestisida di KelurahanJogomerto Kecamatan Tanjunganom Kabupaten Nganjuk.
Perilaku berjalan mengikuti tahaptahap proses dari pengetahuan (knowledge), sikap (attitude), dan tindakan (practice). (Notoadmojo, 2007).

Dalam penelitian Tri Elizadkk,
bahwa Pengetahuan, sikap dan tindakan berpengaruh terhadap perilakupetani dalam penggunaan pestisida. Petani yang memiliki pengetahuanyang cukup baik dalam penggunaan maupunbahaya pestisida, mempengaruhi perilakupetani dalam menggunakan pestisida.

Sikap petani berpengaruh nyata terhadap perilakupetani dalam penggunaan pestisida. Sikap petanidalam memperhatikan petunjuk pemakaian jugasudah cukup baik. Namun ada beberapa respoden petani yang kurang kepeduliannya terhadapdampak penggunaan pestisida secara berlebihan.Hal tersebut diduga disebabkan oleh tingkatpendidikan mereka yang rendah. 


\section{KESIMPULAN DAN SARAN \\ Keseimpulan}

Dari hasil penelitian yang telah dilakukan, maka dapat diambil kesimpulan sebagai berikut:

1. Karakteristik petani di Kelurahan Jogomerto Kecamatan Tanjunganom Kabupaten Nganjuk menurut umur paling tinggi terdapat pada kelompok umur produktif yaitu antara umur16 sampai 64 tahun.

2. Karakteristik responden menurut tingkat pendidikan petani di Kelurahan Jogomerto Kecamatan Tanjunganom Kabupaten Nganjuk, paling tinggi terdapat pada tingkat pendidikan tamat SMP sederajat sebesar $42,3 \%$. Pendidikan resonden rendah karena rata-rata hanya tamat SD, dan SMP. Responden yang berpendidikn SMA hanya $16,9 \%$. Dan responden yang berpendidikan perguruan tinggi hanya $1,4 \%$.

3. Perilaku petani terhadap penggunaan pestisida di Kelurahan Jogomerto Kecamatan Tanjunganom Kabupaten Nganjuk menunjukkan tidak ada petani yang memiliki perilaku baik. Namun banyak petani yang memiliki perilaku cukup baik yaitu sebanyak 68 orang $(95,8 \%)$ dan yang memiliki perilaku kurang baik sebanyak 3 orang $(4,2 \%)$.

4. Penggunaan pestisida oleh petanidi Kelurahan Jogomerto Kecamatan Tanjunganom Kabupaten Nganjuk yang dilakukan dengan caraobservasi menggunakan lembar observasi menunjukkan bahwa penggunaan pestisida yang sesuai pedoman memiliki persentase tertinggi sebesæjadmiko, Riswan Dwi, 2016. Kesehatan dan $60,6 \%$, namun penggunaan pestisida yang tidak sesuai pedoman masih cukup banyak yaitu sebesar 39,4\%. Djojosumarto, Panut, 2008. Pestisida \&

5. Ada hubungan antara umur dengan penggunaan pestisida di KelurahanJogomerto KecamatQijojosumarto, P, 2008. Pestisida dan Tanjunganom Kabupaten Nganjuk.

6. Tidak ada hubungan antara tingkat pendidikan dengan penggunalatiza, pestisida di KelurahanJogomerto
Kecamatan Tanjunganom Kabupaten Nganjuk.

7. Ada hubungan antara perilaku dengan penggunaan pestisida di KelurahanJogomerto Kecamatan Tanjunganom Kabupaten Nganjuk.

\section{Saran}

1. Instansi Pertanian

Sebaiknya perlu dilakukan peningkatan pengetahuan petani dalam menggunakan pestisida, dengan harapan pengetahuan yang dimiliki petani tentang pestisida tepat dan benar yang nantinya akan berperilaku tepat dan benar juga dalam menggunakan pestisida.

2. Instansi Kesehatan

Sebaiknya dilakukan kerjasama bersama dinas pertanian untuk mengetahui tingkat keracunan pestisida pada petani serta di lakukan tes kesehatan secara rutin terhadap petani.

3. Petani

Petani yang telah memiliki pengetahuan baik dan sikap positif dalam menggunakan pestisida harus disertai dengan tindakan yang sesuai dengan aturan penggunaan pestisida.

4. Peneliti Lain

Penelitian lebih lanjut terkait dengan perilaku, umur dan tingkat pendidikan petani untuk mengetahui faktor lain (seperti : tingkat ekonomi, faktor geografis, dsb) yang mengakibatkan petani menggunakan pestisida tidak sesuai aturan..

\section{DAFTAR PUSTAKA}

Keselamatan Kerja. Yogyakarta, Deepublish. Cetakan 1 : Hal. 95-97. Aplikasinya. Jakarta, PT Agromedia Pustaka. Cetakan Pertama : Hal. 5 Aplikasinya. Jakarta, PT Agromedia Pustaka. Cetakan Pertama : 28.

Try dkk, 2013. PERILAKU PETANI DALAM PENGGUNAAN PESTISIDA 
KIMIA (Kasus Petani Cabai di Pek8nemartono dkk, 1992. Bercocok Tanam Padi. Gisting Atas Kecamatan Gisting Jakarta, Yasaguna. Cetakan ke-13. Kabupaten Tanggamus). Vol.1 No.4 Hal 185.

Hal. 334-342, Oktober 2013. Ban\&angiyono, 2015. Metode Penelitian Kuantitatif Lampung : Universitas Lampung.

Gumiarti, et al. 2002. Hubungan Antara Kualitatif dan $R$ \& D. Bandung, Alfabeta. Hal. 93.

Pendidikan, Umur, Jumlah Anak, dsapardi, Sudibyo dan Surahman, 2014. Tingkat Pengetahuan lbu Tentang Metodologi Penelitian Untuk Perkembangan Motorik Pada Anak Mahasiswa Farmasi. Jakarta, Trans Usia 1 - 3 Tahun (Toddler) di Desa Info Media. Hal. 66.

Kemuning Lor Kecamatan Arja\$̧aofah, l'anatut, 2015. Statistika Pendidikan Kabupaten Jember. Jurnal Kesehatan (The Journal of Health) Vol. 3 No. 1 Hal dan Metode Penelitian Kuantitatif. Malang, Madani Media. Hal. 102-104.

1 - 54, Mei 2005. Malang : Politekњlkdang-Undang Nomor 13 Tahun 2003 Kesehatan Malang.

Tentang Ketenagakerjaan.

Hasbullah. 2005. Dasar-dasar IImu Pendidikattami, Jakarta : Raja Grafindo Persada.

Mahyuni, Eka Lestari, 2014. Faktor Resiko Dalam Penggunaan Pestisida Terhadap Keluhan Kesehatan Pada Petani Di Kecamatan Berastagi Kabupaten Karo 2014. 9 (1).http://download.portalgaruda.org/ar ticle. php?article $=315452 \& \mathrm{val}=5543 \&$ titl e=FAKTOR\%20RISIKO\%20DALAM\&awan 20PENGGUNAAN\%20PESTISIDA\%2 OPADA\%20PETANI\%20DI\%20BERAS TAGI\%20KABUPATEN\%20KARO\%20 Khusnul Ulfa, 2016. Hubungan Pengetahuan, Sikap, Dan Tindakan Penggunaan Pestisida Dengan Tingkat Keracunan Pestisida Pada Petani Di Desa Kembang Kuning Kecamatan

Cepogo.http://eprints.ums.ac.id/44461/ 1/NASKAH\%20PUBLIKASI.pdf.29 Juni 2016.

A., \& Dewi M., 2010. Teori dan Pengukuran Pengetahuan, Sikap dan Perilaku Manusia. Yogyakarta: Muha Medika.

$2014 . \quad$ Widoyoko, E.P, 2014. Teknik Penyusunan Notoadmodjo, Soekidjo, 2010. Metodologi Instrumen Penelitian. Yogyakarta, Penelitian Kesehatan. Jakarta, Rineka Pustaka. Cetakan Ketiga. Hal 104-115. Cipta

Notoadmojo, Soekidjo, 2012. Promosi Kesehatan dan Perilaku Kesehatan. Jakarta, Rineka Cipta : Hal.145 Yuantari, MG Catur, dkk. Henna Rya, 2013.

Peraturan Menteri Pertanian Nomor 24 Tahun 2011 Tentang Syarat dan Tatacara Pendaftaran Pestisida. http://ditjenbun.pertanian.go.id/bbpptp medan/tinymcpuk/gambar/file/Perment an\%20No.24\%20Tahun\%202011.pdf. Peraturan Pemerintah Nomor 7 Tahun $1973 \quad 27$ Agustus $201 \overline{3}$. Wudianto, Rini, 1990. Petunjuk Penggunaan

Pestisida. Jakarta, Penebar Swadaya. Cetakan III : Hal. 3.

Tingkat Pengetahuan Petani Dalam Menggunakan Pestisida (Studi Kasus Di Desa Curut Kecamatan Penawangan Kabupaten Grobogan).http://eprints.undip.ac.id/40 659/1/022-_MG_Catur_Yuantari.pdf. 27 Agustus 2013.

Tentang Pengawasan Atas Peredaræłuantari, MG Catur, dkk. Henna Rya, 2013. Penyimpanan dan Penggunaan Pestisida. Tingkat Pengetahuan Petani Dalam Menggunakan Pestisida (Studi Kasus Sudarmo, Subiyakto, 1991. Pestisida. Yogyakarta, Kanisius. Cetakan ke-11: Hal. 22-23.

Di Desa Curut Kecamatan Penawangan Kabupaten Grobogan).http://eprints.undip.ac.id/40 659/1/022-_MG_Catur_Yuantari.pdf. 27 Agustus 2013. 